\title{
Influence of caecal microflora and of two dietary protein levels on the adaptation of the exocrine pancreas: comparative study in germ-free and conventional rats
}

\author{
BY EVELYNE F. LHOSTE*, ISABELLE CATALA, MICHÈLE FISZLEWICZ, \\ A. M. GUEUGNEAU, FRANÇOISE POPOT, PIERRE VAISSADE, \\ TRISTAN CORRING AND ODETTE SZYLIT \\ Laboratoire d'Ecologie et de Physiologie du Système Digestif, INRA, Domaine de Vilvert, \\ F-78350, Jouy-en-Josas, France
}

(Received 20 March 1995 - Revised 19 May 1995 - Accepted 31 May 1995)

\begin{abstract}
Dietary proteins are degraded by both endogenous enzymes and the caecal microflora. In conventional rats the enzyme content of the pancreas depends on the amount of dietary protein. The influence of the caecal microflora on this process is unknown. We report here the effect of the caecal microflora on pancreatic enzymes (proteases, amylase (EC 3.2.1.1), lipase $(E C$ 3.1.1.3)) and on colonic metabolites $\left(\mathrm{NH}_{3}\right.$, urea, short-chain fatty acids). Germ-free and conventional male Fischer rats were fed for 3 weeks with a diet containing 220 or $450 \mathrm{~g}$ protein/ $\mathrm{kg}$ provided as a mixture of fish concentrate and soyabean isolate. The excretion of $\mathrm{NH}_{3}$ and the $\mathrm{pH}$ were specifically increased by the high-protein diet in the germfree rats. The higher production of isobutyrate, valerate and isovalerate in conventional rats fed on the high-protein diet reflected a high bacterial proteolytic activity since these short-chain fatty acids are specific indicators of this activity. The microflora hydrolysed urea to $\mathrm{NH}_{3}$ and maintained the $\mathrm{pH}$ at neutrality whatever the amount of protein in the diet since there were changes in germ-free rats but not in conventional ones. In germ-free rats, amylase, trypsin $(E C$ 3.4.21.4), elastase $(E C$ 3.4.21 .36) and carboxypeptidase $A(E C 3.4 .17 .1)$ specific activities were significantly lower than in conventional rats. The adaptation of the pancreas to the $450 \mathrm{~g}$ protein $/ \mathrm{kg}$ diet was not impaired by the bacterial status except for the specific activity of chymotrypsin $(E C$ 3.4.21.1) which was more increased by this diet in germ-free than in conventional rats. Moreover, the specific activity of lipase increased only in conventional rats fed on the $450 \mathrm{~g}$ protein/ $\mathrm{kg}$ diet. In conclusion, we observed a relationship between the enzyme content of the pancreas and the presence or absence of the caecal microflora suggesting that bacterial fermentation influences pancreatic function.
\end{abstract}

Pancreatic enzymes: Caecal fermentation: Germ-free rat

The fate of dietary proteins in single-stomached mammals depends on both endogenous enzymes and the caecal microflora. Because the amount of protein in the diet influences the caecal microflora and the pancreas, we wondered if a protein that was fermentable by the caecal microflora might influence the endogenous metabolism.

The many ways in which micro-organisms take part in the metabolism of proteins in the gut have been extensively reviewed (Salter, 1973; Visek, 1978; McNeil, 1988). The quantity and quality of dietary proteins determine the quantities of proteins, peptides and amino acids entering the large bowel (Combe et al. 1970). Comparative studies between germ-free (GF) and conventional (CV) rats (Salter, 1973; Combe et al. 1976; Yanagida et al. 1985) provide convincing evidence that the caecal microflora has proteolytic and deaminative activities on undigested nitrogenous matter which produce a large variety of metabolites. 
Consequently, the pattern of nitrogenous excretion is modified by micro-organisms (Combe et al. 1965, 1970). In the caecum and the colon, proteins are degraded with production of short-chain fatty acids (SCFA), $\mathrm{NH}_{3}$, amines and various phenolic acids. Among the SCFA, the branched-chain isobutyric and isovaleric acids arise from the breakdown of valine and isoleucine (Cummings \& Bingham, 1987; Zarling \& Ruchim, 1987). SCFA and $\mathrm{NH}_{3}$ are end-products of the bacterial proteolytic activity.

The influence of fermentation products on endogenous proteolytic activity is not known. When comparing GF and CV rats fed on a liquid or a semi-purified diet, the amounts of protease activity in the pancreas, in its juice and in the lower intestine were almost the same (Borgström et al. 1959; Lepkovsky et al. 1966; Reddy et al. 1969; Genell et al. 1976; Von Juhr, 1980). As pancreatic enzymes reach the foregut they are digested by bacteria like any other endogenous peptide. The role of intestinal bacteria in determining the fate of endogenous enzymes in the caecum is variable (Borgström et al. 1959; Genell et al. 1976). Because of its purity, a protein such as casein is digested in the proximal intestine and, therefore, is not metabolized by the caecal microflora (Corring et al. 1979). In conventional rats, other protein sources do indeed reach the caecum (Rérat, 1978).

In conventional rats the synthesis and secretion of pancreatic enzymes are modulated by the nature and composition of the diet (Corring et al. 1989; Brannon, 1990). The specific activity and synthesis of amylase $(E C 3.2 .1 .1)$ are decreased and those of proteases are increased when the amount of dietary protein is raised at the expense of carbohydrate. Among proteolytic enzymes, only endopeptidases, i.e. trypsin (EC 3.4.21 .4), chymotrypsin $(E C$ 3.4.21 .1) and elastase $(E C$ 3.4.21.36), are influenced by dietary proteins. The control of pancreatic biosynthesis is mostly pretranslational since the alteration of the mRNA expression of specific enzymes is parallel to their biosynthesis (Le Huérou-Luron et al. 1993).

Human-type diets were chosen according to the occidental standards in terms of protein and fat. The average protein intake by humans is $17 \%$ of energy (Committee on Diet and Health, 1989). The levels of dietary protein were also chosen to highlight the pancreatic adaptation to a high protein diet (Corring et al. 1989; Brannon, 1990). The protein intake consisted of a mixture of fish concentrate and soyabean isolate. As a consequence, the fish oil considerably modified the quality of ingested fat in the high-protein diet.

To illustrate the role of caecal microflora we studied the profile of bacterial metabolites. To compare the effects of caecal microflora and diet on the enzyme content of the pancreas, we measured the specific activities of pancreatic enzymes in germ-free and conventional rats. To determine the involvement of gastrointestinal peptides which may regulate pancreatic adaptation to protein-rich diets in rats, we measured the level of cholecystokinin (CCK) in the plasma.

\section{EXPERIMENTAL PROCEDURES}

\section{Animals}

Male Fischer rats aged 6 weeks (122 (SEM10) g), either GF or CV, were housed in wirebottomed cages (two rats per cage). They received $22 \mathrm{~g}$ diet/d, had free access to acidified water and were maintained under a $12 \mathrm{~h}-12 \mathrm{~h}$ light-dark cycle. The GF rats were reared in Trexler-type isolators fitted with a rapid transfer system (LaCahlène, Vélizy, France).

\section{Diets}

The composition of diets is given in Table 1. Proteins (fish plus soyabean) were incorporated into the diet by replacement of mashed potato. The contribution of the potato component to total protein was considered when designing the diets. The protein content 
Table 1. Composition $(\mathrm{g} / \mathrm{kg} \mathrm{DM})$ and crude energy content $(M J / \mathrm{kg} D M)$ of the diets

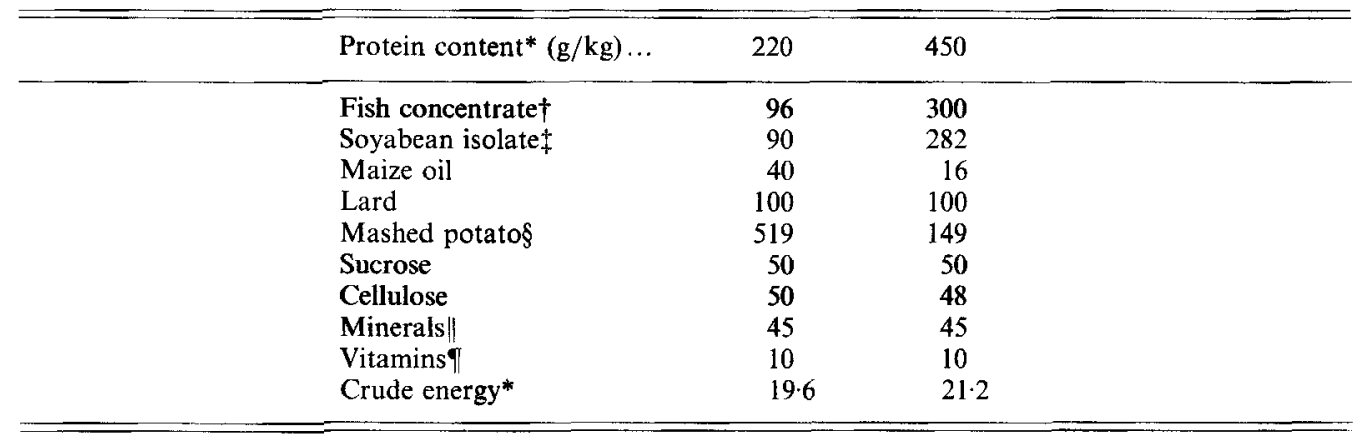

* Measured by the Kjeldahl method $(\mathrm{N})$ and calorimetry.

† Fish concentrate (CPSP 80, Sopropêche Inc., Boulogne/mer, France) contained approximately $(\mathrm{g} / \mathrm{kg})$ : protein 800 , lipid 10 , minerals 5 .

$\ddagger$ Contained approximately $(\mathrm{g} / \mathrm{kg})$ : protein 885 , lipid 15 , cellulose 15 , which were taken into account when balancing the diets.

$\S$ Contained approximately $90 \mathrm{~g}$ protein $/ \mathrm{kg}$.

\| Contained (mg/g mineral complex): potassium phosphate 240 , calcium carbonate 560 , sodium chloride 69 , magnesium oxide 20 , magnesium sulphate 90 , iron sulphate $8 \cdot 6$, zinc sulphate 5 , manganese sulphate 5 , copper sulphate 1, cobalt carbonate 0.02 , potassium iodide 0.04 , ammonium molybdate 0.02 , sodium selenate 0.02 , sodium fluoride $0 \cdot 8$, chromium-potassium sulphate. $12 \mathrm{H}_{2} \mathrm{O} 0.5$.

If Contained (mg/kg diet) : choline concentrate $(500 \mathrm{~g} / 1) 1500$, vitamin E 100, retinyl acetate 10 , cholecalciferol 25 , nicotinic acid 45 , calcium pantothenate 30 , thiamin hydrochloride 10 , riboflavin 10 , pyridoxine hydrochloride 10 , ascorbic acid 100, para-aminobenzoic acid 50, pteroylmonoglutamic acid 2, cyanocobalamin 13.5, Rovimix $\mathrm{H}_{2}$ (Roche, Welwyn Garden City, Herts.) (biotin) 10, menadione 1, myoinositol 50, sucrose 8033.5.

of each diet was assayed by the Kjeldahl method and found to be respectively 220 and $450 \mathrm{~g} / \mathrm{kg}$. The amount of fat remained unchanged since maize oil was replaced by the fat present in the fish concentrate. The diets were sterilized by irradiation at $50 \mathrm{KGy}$ in vacuum-sealed plastic bags. They are referred to as P22 and P45.

\section{Experimental design}

The rats were divided into two groups of twelve GF and two groups of ten $\mathrm{CV}$ rats. In both cases, one group was fed on the P22 diet and the other received the P45 diet for 3 weeks. Dietary intake and weights were recorded every week in order to calculate the consumption index for the whole experiment.

At the end of the first week a nutritional balance study (total energy and $\mathrm{N}$ ) was performed for $5 \mathrm{~d}$. At $4 \mathrm{~d}$ before the study, rats were placed in metabolism cages. Then, faeces of each rat were collected and freeze-dried. Feed intake was measured and rats were weighed before and after each balance.

At the end of the third week the rats were decapitated under diethyl ether anaesthesia without fasting. The arterial blood was collected for a plasma CCK assay. The caecum was removed and the $\mathrm{pH}$ of its content immediately measured. The caecal contents were stored at $-60^{\circ}$ for assay of $\mathrm{NH}_{3}$, uric acid and urea in both GF and $\mathrm{CV}$ rats. In addition, the concentration of SCFA was assayed in CV rats. The pancreas was removed, weighed and stored at $-20^{\circ}$ until biochemical assays.

\section{Analysis of diets and fermentation metabolites}

Diets and freeze-dried faeces were ground and diluted in distilled water. Caecal contents were diluted in phosphate buffer $(0 \cdot 1 \mathrm{~m})$ at the $\mathrm{pH}$ of the caecum. All samples were centrifuged at $12000 \mathrm{~g}$ for $15 \mathrm{~min}$. The fermentation metabolites were assayed in the 
supernatant fractions. $\mathrm{NH}_{3}$ (Dropsy \& Boy, 1961) and urea (Marsh et al. 1965) were assayed in a Technicon autoanalyser. Uric acid was measured by the uricase $(E C$ 1.7.3.3) method using a kit (Boehringer, Mannheim, Germany). SCFA were determined after water extraction using gas chromatography (Ottensheim \& Bartley, 1971). Energy in diets and freeze-dried faeces was assayed in a Gallenkamp calorimeter.

\section{Analysis of blood and pancreas}

Pancreases were homogenized in ice-cold distilled water $(1 \mathrm{~g} / 7 \mathrm{ml})$. Their protein content and the activities of amylase and elastase were measured as published elsewhere (Lhoste et al. 1993). The activity of lipase was assayed by measuring the decrease in turbidity of a solution of trioleine in u.v. light using a kit (Boehringer, Mannheim). The activity of chymotrypsin was measured after a $1-2 \mathrm{~h}$ trypsin activation in $0 \cdot 1 \mathrm{M}$-Tris(hydroxymethyl)amino methane ((Tris)-Cl), $0.2 \mathrm{M}-\mathrm{CaCl}_{2}, \mathrm{pH} \mathrm{7.9}$, at $4^{\circ}$ (Bieth et al. 1968) and that of trypsin was assayed after a $24 \mathrm{~h}$ enterokinase (EC 3.4.21.9) activation in $5 \mathrm{~mm}$-(Tris)-Cl, $40 \mathrm{mM}-\mathrm{NaCl}, 20 \mathrm{mM}-\mathrm{CaCl}_{2}, \mathrm{pH} 9$, at $4^{\circ}$ (Bieth et al. 1966). The activity of carboxypeptidase $\mathrm{A}(E C 3.4 .17 .1)$ was determined after an activation by pancreatic trypsin at $37^{\circ}$ for $1-2 \mathrm{~h}$ in $5 \mathrm{~mm}$-(Tris)-Cl, $40 \mathrm{~mm}-\mathrm{NaCl}, 20 \mathrm{~mm}-\mathrm{CaCl}_{2} \mathrm{~m}, \mathrm{pH} 7 \cdot 9$ (Yamasaki et al. 1963).

CCK was assayed in the plasma by radioimmunoassay as published previously (Cuber et al. 1989). The antiserum reacted against CCK-8, CCK-33 and CCK-39 with the same sensitivity (90\%) and cross-hybridized with gastrin 17-II (12\%) and non-sulphated CCK$8(0.06 \%)$.

\section{Statistical analysis}

Results are expressed as the mean and standard error of the mean (SEM). Experimental values were compared by a two-way ANOVA with subsequent Bonferroni test. SCFA were only assayed in conventional rats; therefore, they were compared by a one-way ANOVA followed by a $t$ test. All statistical analyses were performed with the SAS software package (Statistical Analysis Systems Institute Inc., Cary, NC, USA).

\section{RESULTS}

Body weight, feed intake and apparent digestibility

During the 3-week experiment, GF and CV rats gained similar amounts of weight although the latter ate less. Consequently, the consumption index (feed intake/weight gain) was lower in GF than $\mathrm{CV}$ rats $(P=0.0045)$ (Table 2$)$.

During the 1-week balance study the energy and $\mathbf{N}$ digestibilities ((amount in feed ingested-amount in faeces)/amount in feed ingested) were significantly linked to the bacterial status of rats $(P=0.0062$ and $P=0.0014$ respectively). None of these variables was influenced by the protein level of the diet. The energy digestibility was significantly different between $\mathrm{P} 22 \mathrm{GF}$ and $\mathrm{CV}$ rats and the $\mathrm{N}$ digestibility was significantly different between P45 GF and CV rats (Table 2).

\section{Fermentation in the caecum}

The $\mathrm{pH}$ and the concentrations of $\mathrm{NH}_{3}(P=0.0001)$ and urea $(P=0.0209)$ in the caecal contents were significantly affected both by the bacterial status of the rats and by the diets (Table 3). Moreover, there was a strong interaction between the presence of bacteria and the protein content of the $\operatorname{diet}\left(P=0.0001\right.$ for $\mathrm{pH}, 0.0002$ for $\mathrm{NH}_{3}$ and 0.0445 for urea). In GF rats the caecal $\mathrm{pH}$ was lower and the urea concentration was higher after the P45 than after the P22 diet $(P<0.05$, respectively 0.9 - and 1.6 -fold) whereas in CV rats these variables were not modified by the diets. The concentrations of uric acid and $\mathrm{NH}_{3}$ followed the same pattern but the differences were not statistically significant. In $\mathrm{CV}$ rats the $\mathrm{NH}_{3}$ 


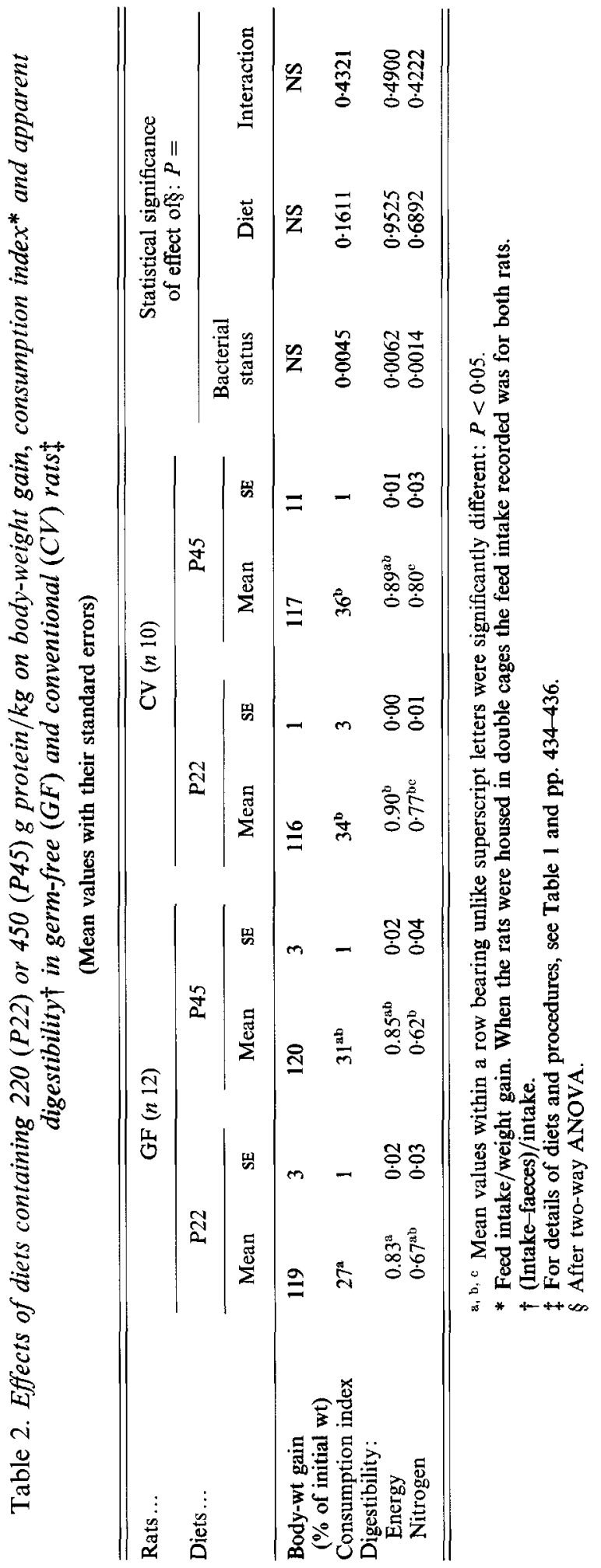




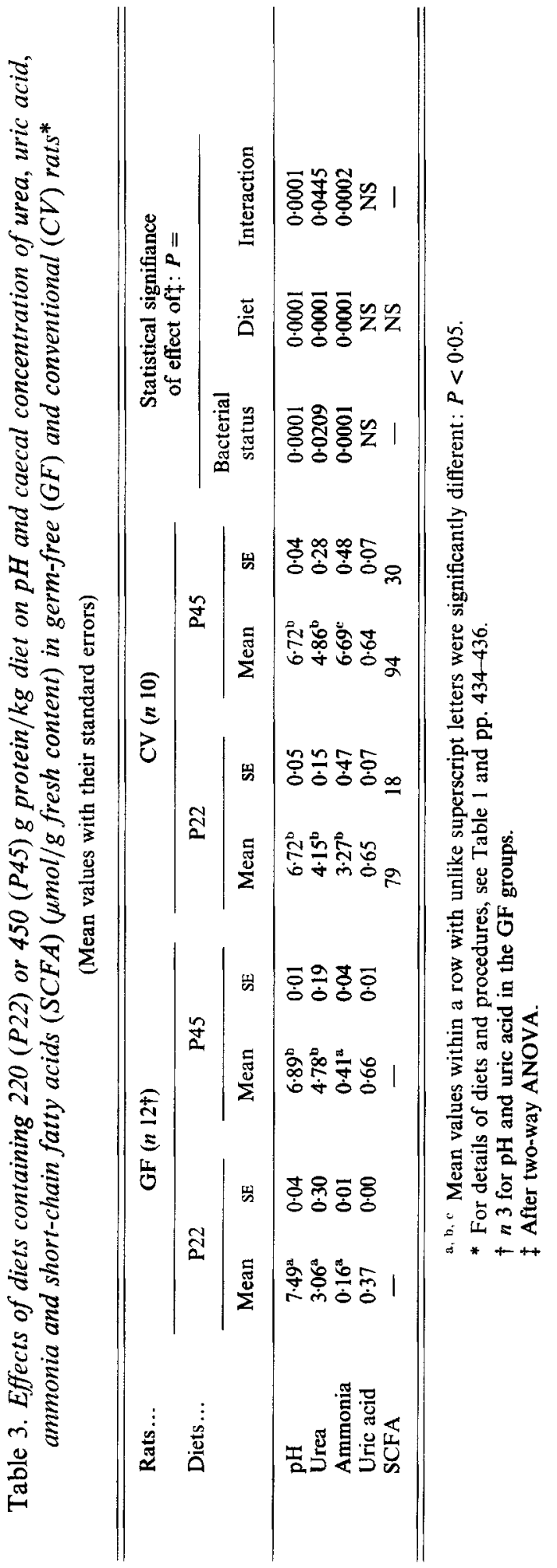




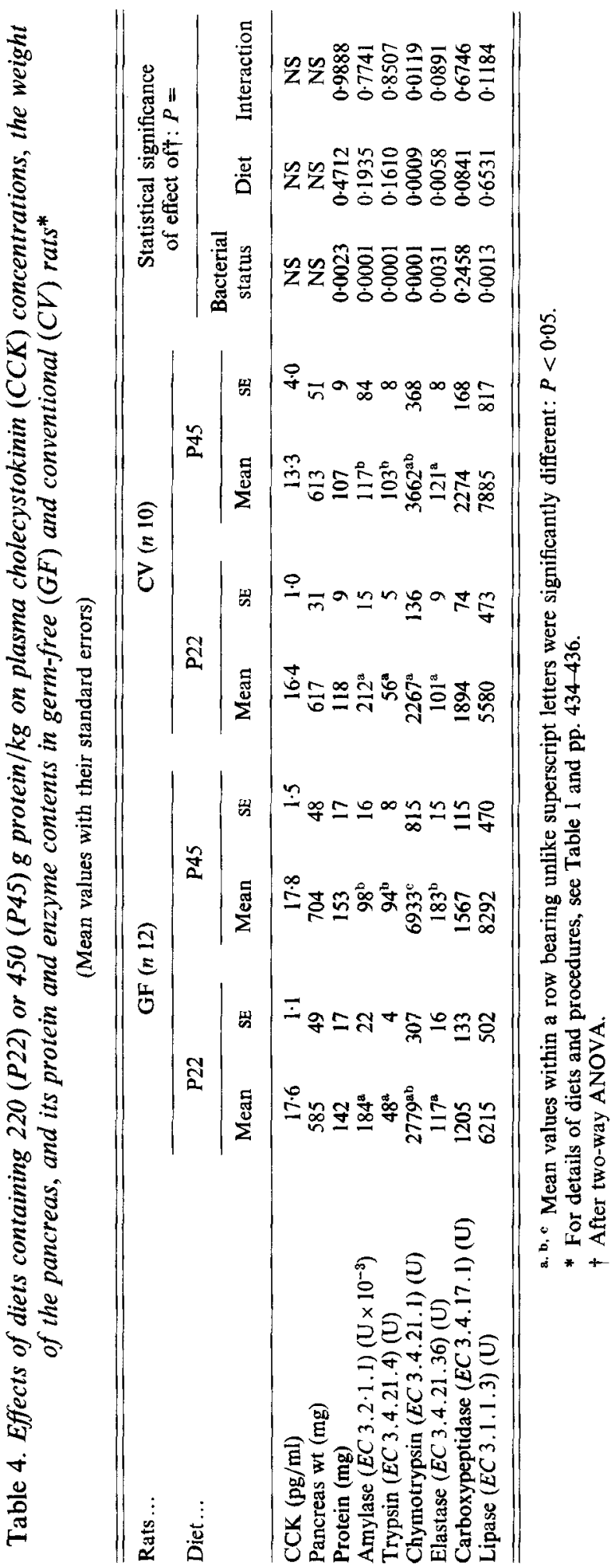




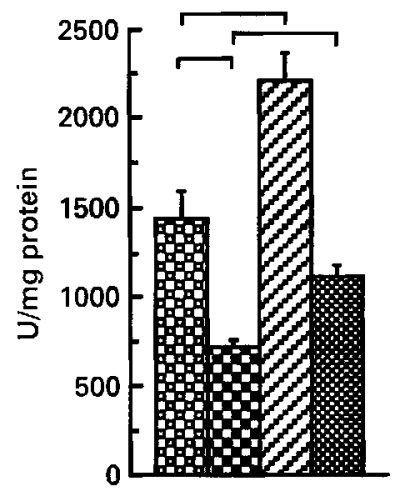

Amylase

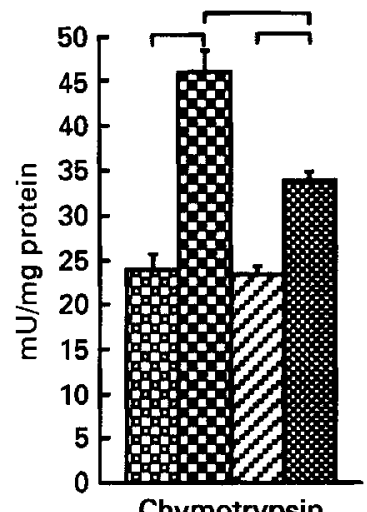

Chymotrypsin

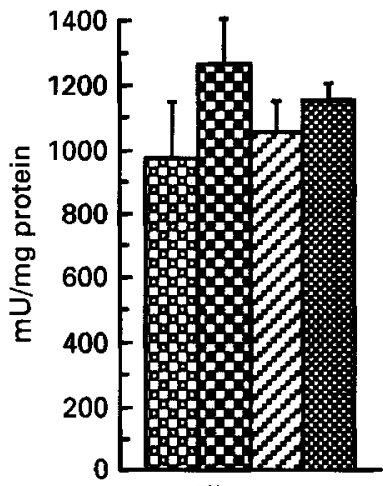

Elastase

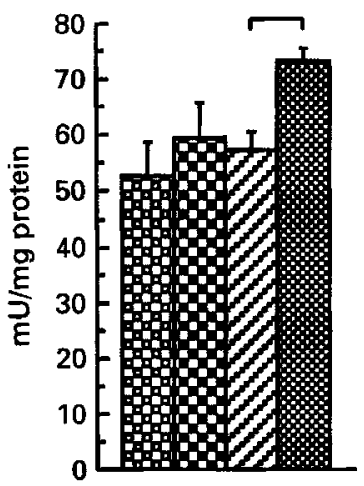

Lipase
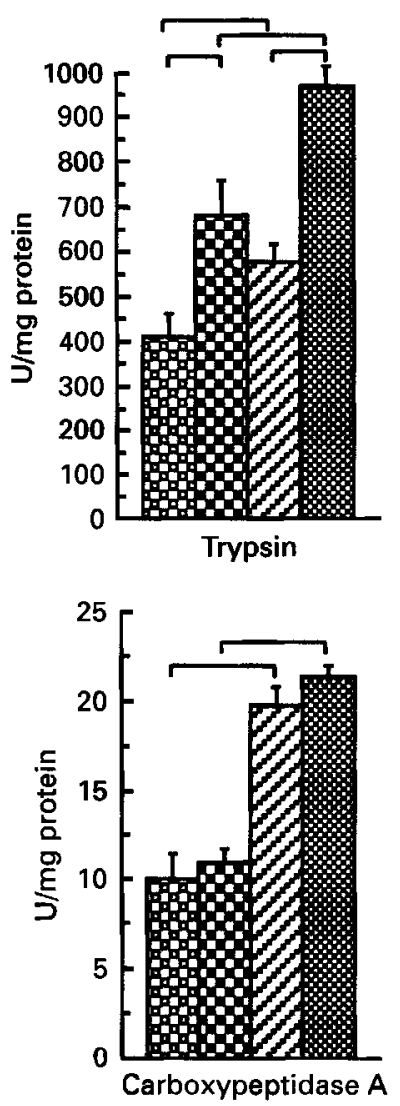

Fig 1. Effects of diets containing $220(\mathrm{P} 22)$ or $450(\mathrm{P} 45) \mathrm{g}$ protein $/ \mathrm{kg}$ on the specific activities of pancreatic enzymes in germ-free (GF; $n$ 12) and conventional (CV; $n$ 10) rats. The specific activity is the ratio of the total pancreas content of one specific enzyme to the protein content of the pancreas. Values are means with their standard errors represented by vertical bars. (䁂), GF P22; (圂), GF P45; (囚), CV P22; (畻), CV P45. Values for groups linked by horizontal lines were significantly different, $P<0.05$. For details of diets and procedures, see Table 1 and pp. 434-436.

concentration significantly increased 2 -fold after the P45 diet $(P<0.05)$ and it was sixteen times higher than in their GF counterparts. Other variables were not altered.

In CV rats the weights of caecal contents were not different (4.86 (SE 0.3) g in P22 and $4 \cdot 48$ (SE 0.20) $\mathrm{g}$ in P45). The SCFA concentration (Table 3) and total caecal content (results 
not shown) were not altered by the protein intake. The proportions of isobutyric, isovaleric and valeric acids increased respectively $1.7,1.7$ and 1.5 -fold in P45 v. P22 diets $(P<0.01$; the isobutyric:isovaleric:valeric acid ratio was $0 \cdot 74: 1 \cdot 79: 0 \cdot 76$ in the $P 22$ group). The profile of other SCFA was not modified (the acetate:propionate:butyrate ratio was $69: 15: 14)$.

\section{Plasma cholecystokinin level, pancreas weight and protein content}

The plasma CCK was not influenced by the rat bacterial status or by the diet. The pancreas weight was unaffected by any treatment. The protein content of the pancreas was higher in GF than in CV rats $(P=0.0023)$ (Table 4).

\section{Pancreatic enzyme contents}

The variations in total enzyme content are reported in Table 4 while the specific activities of the enzymes are illustrated in Fig. 1. The specific activity is the ratio of the pancreas total content of one specific enzyme to the protein content. It reflects the relative modulation of the biosynthesis of each enzyme independent of a possible hypertrophy of the gland.

The specific activities of amylase and trypsin were influenced by the bacterial status of the rats and by the diets they consumed $(P=0.0001)$. The pancreatic contents of amylase and trypsin were affected by the $\operatorname{diet}(P=0.001)$ but not by the bacterial status. In the GF $\mathrm{P} 22$ rats they represented respectively $0.6-$ and 0.7 -fold those of $\mathrm{CV}$ rats fed on the same $\operatorname{diet}(P<0.05)$. When GF or $\mathrm{CV}$ rats ingested the $\mathrm{P} 45$ diet the amylase specific activity and its total pancreatic content decreased $(0.5$-fold, $P<0.05)$ while those of trypsin increased 1.7-fold $(P<0.05)$.

The specific activity of chymotrypsin was influenced both by the bacterial status and by the diet ( $P=0.0012$ and $P=0.0001$ respectively), and we noticed a significant interaction between both criteria $(P<0 \cdot 0006)$. The specific activity was identical in GF P22 and CV $\mathrm{P} 22$ rats. When rats ingested the $\mathrm{P} 45$ diet the chymotrypsin specific activity increased 2-fold in GF and $1 \cdot 5$-fold in $\mathrm{CV}$ rats $(P<0 \cdot 05)$. The total content of the gland followed the same pattern.

The specific activity of elastase was not affected by either factor. The total content of this enzyme was modified by the diet $(P=0.0031)$ and the bacterial status $(P=0.0058)$. The content was identical in GF P22, CV P22 and CV P45 rats. When GF rats ingested the P45 diet, it increased $1 \cdot 5$-fold $(P<0 \cdot 05)$.

The specific activity of carboxypeptidase A was only influenced by the bacterial status of the rats $(P=0.0001)$. In the GF $P 22$ rats it represented 0.5 -fold that of $C V$ rats fed on the same diet $(P<0.05)$. When GF or CV rats ingested the P45 diet, it was not changed. The total content of the pancreas was not altered by the diets or the bacterial status.

The specific activity and total content of lipase was affected by the diet $(P=0.0352$ and $P=0.0008$ respectively) but not by the bacterial status. Its specific activity was only increased in CV rats fed on the P45 diet compared with the P22 diet $(1 \cdot 3$-fold, $P<0.05)$.

\section{DISCUSSION}

There is little information on the importance of the caecal microflora to the general $\mathrm{N}$ metabolism of the host. The present findings suggest that the bacterial flora promotes the digestion of non-readily available proteins (such as fish or soyabean) while other studies have shown that a more digestible protein (such as casein) is digested and absorbed less efficiently in the small intestine of GF rats. Indeed, the rats' growth was not impaired while the consumption index was lower in GF than in CV rats fed on our diet. Since GF rats ate less and their energy and $N$ digestibilities were lower than in CV rats they may have had a better retention of absorbed $\mathrm{N}$. When fed on a $100 \mathrm{~g}$ casein $/ \mathrm{kg}$ diet, both $\mathrm{GF}$ and $\mathrm{CV}$ rats consumed the same amount of feed, but the latter gained more weight suggesting that 
casein was absorbed less efficiently in the small intestine by GF than CV rats (Coates, 1973; Lin \& Visek, 1991).

Comparison between GF and CV rats showed a regulating action of the caecal microflora. In GF rats the caecal $\mathrm{pH}$ decreased and the caecal contents of $\mathrm{NH}_{3}$ and urea increased with the $\mathrm{P} 45$ diet, while in $\mathrm{CV}$ rats only $\mathrm{NH}_{3}$ was increased. Such a difference has been observed previously between GF and CV rats fed on a semi-purified diet containing various amounts of casein (Demigné \& Remesy, 1979; Lupton \& Marchand, 1989; Lin \& Visek, 1991). The urea content was not altered in CV rats since, in mammals, bacterial ureases prevent the accumulation of urea in the caecum by hydrolysis of urea into $\mathrm{NH}_{3}$ (Levenson et al. 1959). As demonstrated earlier (Coates, 1968), urea is the end-product of amino acid catabolism in the absence of micro-organisms and is increased with the amount of dietary protein. Although the total weight of the caecal content was not measured in the present study we have observed repeatedly that the caecum of GF rats is much enlarged and has a content two to three times higher than that of CV rats whatever the diet (Dufour, 1989 and unpublished results). In the light of these results, the total amount of $\mathrm{NH}_{3}$ in the caecum is still much higher in the CV rats while that of urea is identical.

The differences observed between CV and GF rats may reflect an important proteolytic activity of the caecal microflora. When $\mathrm{CV}$ rats were fed on a high-protein diet the isobutyric, isovaleric and valeric acids, which are end-products of protein digestion, were increased while other SCFA were not modified. SCFA were only present in the caecums of $\mathrm{CV}$ rats since they are produced by the caecal microflora (Meslin et al. 1993). End-products of protein metabolism include substances such as amines, phenols and indoles, some of which, like $\mathrm{NH}_{3}$, are involved in large bowel disease (Levenson et al. 1959; Visek, 1978; McBurney et al. 1987).

The most original finding of the present study was the importance of the caecal microflora to the function of the pancreas. The protein content of the pancreas was higher in GF than in CV rats. This suggests that the pancreas was slightly hypertrophic. However, the difference was very modest and probably not relevant. Furthermore, the weight of the pancreas and its DNA content (results not shown) were not affected by the bacterial status.

The bacterial status altered preferentially the exocrine pancreatic function. The specific activity (Unit/mg protein content) only indicates the relative variation of a specific enzyme regardless of the global effect on protein content. The specific activities of amylase, trypsin and carboxypeptidase $A$ were lower in GF than $\mathrm{CV}$ rats. In GF rats fed on a standard diet the structure of dietary nutrients is probably of great importance in the influence of the caecal microflora on pancreas function. Other authors (Lepkovsky et al. 1966; Reddy et al. 1969) did not demonstrate any modification of pancreatic enzyme activities in rats fed with semi-purified diets containing casein, whatever the bacterial status. We suggest that these products hydrolysed in the proximal intestine did not produce bacterial metabolites which, directly or indirectly, might impair pancreatic enzyme biosynthesis. In the CV groups the protein content of the diet induced an adaptation of the synthesis of pancreatic enzymes. This is a common feature (Corring et al. 1989; Brannon, 1990). We showed that in GF rats the pancreas also adapts to the dietary composition. Furthermore, the activity of chymotrypsinogen is even higher in GF rats. Therefore, the caecal microflora is not involved in the adaptation of the pancreas to high-protein diets. The increase in lipase activity induced by the P45 diet was only present in CV rats, suggesting the involvement of caecal microflora.

How could the caecal microflora act on the pancreas? Since the plasma level of CCK, a major regulatory peptide of the function of exocrine pancreas, was not altered in GF rats, this peptide may not be involved. As the secretion of insulin was delayed and decreased in GF rats, the exogenous pancreas may be influenced through its endocrine part (Wiech et 
al. 1967). The plasma levels of enteroglucagon, the pancreatic polypeptide and gastrin were lower in GF than in CV rats (Goodlad et al. 1989). Such peptides stimulate the biosynthesis of pancreatic enzymes and therefore may be intermediate in the action of the caecal microflora on the pancreatic function. The caecal microflora may also affect the pancreas via its metabolites. In fact, SCFA can stimulate amylase release from the rat pancreas directly (Ohbo et al. 1989). However, intracaecal administration of SCFA for 1 week did not alter the pancreas of conventional rats (E. F. Lhoste and I. Schmidt, unpublished results). This hypothesis is taken into account in gnotobiotic studies now in progress in our laboratory.

The authors thank Joel Galle for preparing the figures and Martine Delaire, Rosa Durao, and Sandra Letort for their careful technical assistance.

\section{REFERENCES}

Bieth, J., Metais, P. \& Warter, J. (1966). Etude des protéases pancréatiques I. Dosage de la trypsine par la benzoylarginine-P-nitroanilide et ses applications. (Study of pancreatic proteases. The assay of trypsin by benzoyl-P-nitroanilide and its applications). Annales Biologie Clinique 24, 787-803.

Bieth, J., Metais, P. \& Warter, J. (1968). Etude des protéases pancréatiques II. Dosage de la chymotrypsine par la succinyl-phénylalanine-P-nitroanilide et ses applications. (Study of pancreatic proteases. The assay of chymotrypsin by succinyl-phenylalanine-P-nitroanilide and its applications). Annales Biologie Clinique 26, 143-158.

Borgström, B., Dahlqvist, A., Gustafsson, B. E., Lundh, G. \& Malmquist, J. (1959). Trypsin, invertase and amylase contents of faeces of germfree rats. Proceedings of the Society for Experimental Biology and Medicine 102, 154-155.

Brannon, P. M. (1990). Adaptation of the exocrine pancreas to diet. Annual Review of Nutrition 10, 85-105.

Coates, M. E. (1968). Nutrition and metabolism. In The Germ-free Animal in Research, pp. 161-179 [M. E. Coates, H. A. Gordon and B. S. Wostmann, editors]. New York: Academic Press.

Coates, M. E. (1973). Gnotobiotic animals in nutrition research. Proceedings of the Nutrition Society 32, 53-58.

Combe, E., Demarne, Y., Gueguen, L., Ivorec-Szylit, O., Meslin, J. C. \& Sacquet, E. (1976). Some aspects of the relationships between gastro-intestinal flora and host nutrition. World Review of Nutrition and Dietetics 24, $1-57$.

Combe, E., Penot, E., Charlier, H. \& Sacquet, E. (1965). Métabolisme du rat "germ-free". Teneurs des contenus digestifs en certains composés azotés, en sodium et en potassium. Teneurs de quelques tissus en acides nucléiques (Metabolism of the germ-free rat. Some nitrogenous compounds, sodium and potassium contents of the intestine. The nuclei acid content of some tissues). Annales de Biologie Animale, Biochimie, Biophysique $\mathbf{5}$, 189206.

Combe, E., Pion, R. \& Sacquet, E. (1970). Influence de la nature et du taux des protéines alimentaires sur la composition en acides aminés du contenu du caecum du rat axénique (Influence of the nature and amount of dietary proteins on the amino acid contents of the caecum of axenic rats). Annales de Biologie Animale, Biochimie, Biophysique 10, 697-702.

Committee on Diet and Health (1989). Diet and Health, Implications of Reducing Chronic Diseases Risk. Washington, DC: National Academy Press.

Corring, T., Juste, C. \& Lhoste, E. F. (1989). Nutritional regulation of pancreatic and biliary secretions. Nutrition Research Reviews 2, 161-180.

Corring, T., Moreau, C. \& Ducluzeau, R. (1979). Comparative apparent digestibility of casein in holoxenic, axenic, and Clostridium bifermentans monoassociated rats. American Journal of Clinical Nutrition 32 , $1231-1237$.

Cuber, J. C., Vilas, F., Charles, N., Bernard, C. \& Chayvialle, J. A. (1989). Bombesin and nutrients stimulate release of CCK through distinct pathways in the rat. American Journal of Physiology 256, G989-G996.

Cummings, J. H. \& Bingham, S. A. (1987). Dietary fibre, fermentation and large bowel cancer. Cancer Surveys 6, 601-614.

Demigné, C. \& Remesy, C. (1979). Urea cycling and ammonia absorption in vivo in the digestive tract of the rat. Annales de Biologie Animale, Biochimie, Biophysique 19, 929-935.

Dropsy, G. \& Boy, J. (1961). Détermination de l'ammoniémie, méthode automatique par dialyse (Assay of ammoniaemia: an automatic method using dialysis). Annales Biologie Clinique Paris 19, 313-317.

Dufour, C. (1989). Impacts de la microflore digestive sur les effets nutritionnels et physiologiques des fibres alimentaires chez le rat hétéroxénique à flore humaine (Influence of a human microflora on the effects of dietary fibres on nutritional and physiological parameters in the heteroxenic rat). Thesis, Institut National Agronomique, Paris-Grignon. 
Genell, S., Gustafsson, B. E. \& Ohlsson, K. (1976). Quantification of active pancreatic endopeptidases in the intestinal contents of germfree and conventional rats. Scandinavian Journal of Gastroenterology 11, 757-762.

Goodlad, R. A., Ratcliffe, B., Fordham, J. P., Ghatei, M. A., Domin, J., Bloom, S. R. \& Wright, N. A. (1989). Plasma enteroglucagon, gastrin and peptide $\mathrm{YY}$ in conventional and germ-free rats refed with a fibre-free or fibre-supplemented diet. Quarterly Journal of Experimental Physiology 74, 437-442.

Le Huérou-Luron, I., Lhoste, E., Wicker-Planquart, C., Dakka, N., Toullec, R., Corring, T., Guilloteau, P. \& Puigserver, A. (1993). Molecular aspects of enzyme synthesis in the exocrine pancreas with emphasis on development and nutritional regulation. Proceedings of the Nutrition Society 52, 301-313.

Lepkovsky, S., Furuta, F., Ozone, K. \& Koike, T. (1966). The proteases, amylase and lipase of the pancreas and intestinal contents of germ-free and conventional rats. British Journal of Nutrition 20, 257-261.

Levenson, S. M., Crowley, L. V., Horowitz, R. E. \& Malm, O. J. (1959). The metabolism of carbon-labeled urea in the germfree rat. Journal of Biological Chemistry 234, 2061-2062.

Lhoste, E. F., Fiszlewicz, M., Gueugneau, A. M., Wicker-Planquart, C., Puigserver, A. \& Corring, T. (1993). Effects of dietary proteins on some pancreatic mRNAs encoding digestive enzymes in the pig. Journal of Nutritional Biochemistry 4, 143-152.

Lin, H. C. \& Visek, W. J. (1991). Large intestinal $\mathrm{pH}$ and ammonia in rats: dietary fat and protein interactions. Journal of Nutrition 121, 832-843.

Lupton, J. R. \& Marchand, L. J. (1989). Independent effects of fiber and protein on colonic luminal ammonia concentration. Journal of Nutrition 119, 235-241.

Marsh, W. H., Fingerhut, B. \& Miller, H. (1965). Automated and manual direct methods for the determination of blood urea. Clinical Chemistry 11, 624-627.

McBurney, M. I., Van Soest, P. J. \& Jeraci, J. L. (1987). Colinic carcinogenesis: the microbial feast or famine mechanism. Nutrition and Cancer 10, 23-28.

McNeil, N. I. (1988). Nutritional implications of human and mammalian large intestinal function. World Review of Nutrition and Dietetics 56, 1-42.

Meslin, J. C., Andricux, C., Sakata, T., Beaumatin, P., Bensaada, M., Popot, F., Szylit, O. \& Durand, M. (1993). Effects of galacto-oligosaccharide and bacterial status on mucin distribution in mucosa and on large intestine fermentation in rats. British Journal of Nutrition 69, 903-912.

Ohbo, M., Katoh, K. \& Sasaki, Y. (1989). Effects of short-, medium-, and long-chain fatty acids on amylase release from pancreatic segments of rats. Australian Journal of Applied Sciences 2, 193-194.

Ottensheim, O. M. \& Bartley, D. A. (1971). Improved gas chromatography separation of free acids $\mathrm{C}_{2}-\mathrm{C}_{5}$ in dilute solution. Analytical Chemistry 43, 952-955.

Reddy, B. S., Pleasants, J. R. \& Wostmann, B. S. (1969). Pancreatic enzymes in germfree and conventional rats fed chemically defined, water soluble diet free from natural substances. Journal of Nutrition 97, 327-334.

Rérat, A. (1978). Digestion and absorption of carbohydrates and nitrogenous matters in the hindgut of the omnivorous nonruminant animal. Journal of Animal Science 46, 1808-1837.

Salter, D. N. (1973). Influence of gut micro-organisms on utilization of dietary protein. Proceedings of the Nutrition Society 32, 65-71.

Visek, W. J. (1978). The mode of growth promotion by antibiotics. Journal of Animal Science 46, 1147-1169.

Von Juhr, N. C. (1980). Intestinale Enzymeaktivität bei keimfreien und konventionellen Ratten und Mäusen (Intestinal enzyme activities in germ-free and conventional rats and mice). Zeitschrift fuer Versuchstierkunde 22, 197-203.

Wiech, N. L., Hamilton, J. G. \& Miller, O. N. (1967). Absorption and metabolism of dietary triglycerides in germfree and conventional rats. Journal of Nutrition 93, $324-330$.

Yamasaki, M., Brown, J. R., Cox, D. J., Greenshields, R. N., Wade, R. D. \& Neurath, H. (1963). Procarboxypeptidase A-S6. Further studies of its isolation and properties. Biochemistry 2, 859-866.

Yanagida, K., Takahashi, M., Honma, C., Kametaka, M. \& Yamanaka, M. (1985). Ammonia in intestinal contents from germfree rats. Experimental Animals 34, 463-465.

Zarling, E. J. \& Ruchim, M. A. (1987). Protein origin of the volatile fatty acids isobutyrate and isovalerate in human stool. Journal of Laboratory and Clinical Medicine 109, 566-570. 